\title{
Building a Clean Machine: Anti-Corruption Coalitions and Sustainable Reform
}

\author{
Michael Johnston \\ Department of Political Science \\ Colgate University \\ Hamilton, New York 13346 \\ Tel: $+1-315-228-7756$ \\ Fax: +1-315-228-7883 \\ mjohnston@mail.colgate.edu \\ http://people.colgate.edu/mjohnston/personal.htm \\ Sahr J. Kpundeh \\ Governance Team, World Bank Institute \\ Governance, Finance and Regulation Division (WBIGF) \\ MSN J3-304, 1818 H Street, N.W., Washington, D.C. 20433 \\ Tel. 202 473-6783; Fax. 202 676-9874 \\ skpundeh1@,worldbank.org \\ http://www.worldbank.org/wbi/governance
}

World Bank Policy Research Working Paper 3466, December 2004

The Policy Research Working Paper Series disseminates the findings of work in progress to encourage the exchange of ideas about development issues. An objective of the series is to get the findings out quickly, even if the presentations are less than fully polished. The papers carry the names of the authors and should be cited accordingly. The findings, interpretations, and conclusions expressed in this paper are entirely those of the authors. They do not necessarily represent the view of the World Bank, its Executive Directors, or the countries they represent. Policy Research Working Papers are available online at http://econ.worldbank.org.

The authors thank Soji Apampa, Luca Barbone, Guy Darlan, Phyllis Dininio, K. Sarwar Lateef, Anne Pitcher, Jack Titsworth, and Yongmei Zhou for the comments and suggestions they made regarding earlier versions of this paper. 


\begin{abstract}
Many societies have limited corruption through the broad-based mobilization of a diverse range of interests willing and able to defend themselves by making meaningful demands for accountability of, and limits upon, official power, and for an end to illicit advantages enjoyed by others. Historically such a process has taken place gradually, as political development has proceeded and the base of participation broadens. But today's highcorruption societies cannot wait for several generations to see such developments take place. We argue that social action coalitions, linking public and private actors, are a way to mobilize these sorts of participation and advocacy. Such coalitions are neither a new idea nor a guarantee of successful reforms; indeed, in many instances they win out by default as an anti-corruption strategy. But we contend that if sustained by careful planning and a diverse set of incentives, they can reinforce political will and enhance the strength of civil society. Coalition-building efforts are underway in many societies. But too often they have focused only on anti-corruption tactics and pursuing their own growth, rather than looking at the coalition-building process in more general terms. We do this, in Part I, by employing Wilson's (1973) analysis of the incentives that motivate and reward participation in organizations. This approach helps us identify ways in which the anti-corruption goals can be augmented by other kinds of appeals, even when material incentives are scarce. We also identify four stages of the coalition-building processformation, credibility, expansion, and transformation - in which differing combinations of incentives will be necessary to address the group's most important problems and opportunities. Part II examines two important coalition-building efforts in light of the discussion thus far-Ghana's Anti-Corruption Coalition, and the Bangalore Agenda Task Force in Bangalore, Karnataka State, India. In Part III we link those cases to our broader analysis, suggesting that while purposive incentives are common in the early phases of all coalitions, other varieties must be added to the mix. Wilson's scheme points to ways in which the imaginative use of incentives can aid the transition from one phase of coalition development to the next. We conclude with general strategic issues, suggesting ways in which our analysis can be applied to those questions given the important variations to be found among cases.
\end{abstract}




\section{PART I: THE COALITION-BUILDING STRATEGY}

\section{Introduction: Sustaining Reform}

Societies rarely bring corruption under control through penalties, morality campaigns, or administrative reforms alone. Anti-corruption coups and the "one-man show" strategy usually are even less successful: even if actually intended as reforms - which usually they are not - they weaken civil society and the press, chill political competition and demands for accountability, and substitute intimidation for transparency. More often, corruption has been reduced not so much by overreaching visions of good government as by the growing ability of people and groups outside the state to defend themselves against official abuse and to check the unfair advantages of others. In 17th-century England, for example, Parliament became better able to curb royal abuses of power in the course of a long struggle with the Crown over issues as diverse as taxation, religion, and crown patronage (Roberts, 1980; Johnston, 1993). That sort of reform is a long-term process bearing real costs and risks, and often features - indeed, requires - considerable political contention and wrangling. But because it is sustained by self-interest and credible incentives it draws major segments of society into the process of reform, where they can demand and reward good governance in the course of pursuing their own political and economic goals.

This suggests that despite the past decade's advances in the areas of good governance, administrative reform, and economic liberalization, there is still a major missing piece in our reform repertoire: politics. By this we do not mean partisan interventions into domestic politics processes by the Bank or other international organizations. These are quite sensibly made off-limits to the Bank by its Terms of Agreement. Instead, we refer to ways in which people and groups within society can be mobilized to act against corruption in ways that are sustained by their own lasting interests. Our specific focus is upon building social action coalitions: initiatives that encourage and enable people and groups within developing societies to develop their own political capabilities and to share their resources. Not only is that a complex challenge; it must also be done in ways that make it clear anti-corruption coalitions are not just partisan interventions under another guise. With proper understanding and support, however, social action coalitions against corruption can become partners with reformminded officials, and can develop significant anti-corruption strength from within the societies that need reform most.

This paper offers a conceptual analysis of the sorts of incentives and exchanges that hold coalitions together, and of the stages and pitfalls anyone seeking to build a social action coalition will encounter. In Part I we borrow from James Q. Wilson's (1973) theory of organizational incentive systems to discuss the sorts of appeals and rewards an anti-corruption coalition can offer to diverse constituencies, and suggest that these are more numerous and flexible than a focus on material exchanges alone would indicate. We then outline characteristic stages of coalition development, defined by the key challenges leaders will confront, and suggest ways in which repertoires of incentives can be altered 
or expanded to address each challenge. Part II takes up two coalition examples - the Ghana Anti-Corruption Coalition, and the Bangalore Agenda Task Force in India. These are not intended to illustrate all possible variations on the coalition-building theme, nor to provide guiding examples for all other cases; rather, they illustrate the ways incentives can be deployed, and problems - notably, that of the coalition's degree of autonomy visà-vis government - that all coalition architects must address. In Part III we develop conclusions regarding coalitions as tools of anti-corruption strategy, drawing upon both the conceptual discussion and our two examples. The result is not a step-by-step, "howto" guide for building coalitions: variations in social and political circumstances, and in the kinds of corruption problems that must be confronted, make any such attempt futile. Instead, we hope to influence the ways anti-corruption activists see their tasks, and understand the resources and constraints within which they must work. Coalitions, we argue, are a way to enhance political will and strengthen civil society, but they must be built and sustained from the inside out, linking anti-corruption action to the interests and agendas of those they seek to mobilize.

Low- and High-Corruption Syndromes. Comparing levels of corruption remains an inexact science (Johnston, 2002), and corruption problems can vary in significant ways from one time and place to the next. But where the problem seems to be under control, a variety of political, economic, and social processes and institutions play key roles. These include sound political and economic institutions. In addition, vigorous but open and well-structured competition in both arenas means there are alternatives to exploitation and meaningful avenues of recourse and appeal. These are not only worthwhile goals in themselves, but also help moderate corruption and, over the long run, facilitate further development. There is no society that is totally free of corruption, and no strategy can guarantee successful development forever. Still, sustained and balanced development in both the political and economic realms can foster a low-corruption equilibrium (Johnston, 1998).

Elsewhere, however, entrenched corruption hampers political and economic development, undermining institutions and impeding competitive participation in both arenas. Anti-corruption forces and civil society remain weak; formal boundaries and links between politics and the economy are poorly institutionalized and lack credibility, while the real connections and decision processes are the corrupt ones. In such a setting, corruption both reflects and helps perpetuate weak and uneven development; it faces only weak institutional constraints and countervailing forces, and consequently can become deeply entrenched. When that happens, those who play by the rules - and thus, losehave nowhere to take a stand. Citizens will more likely respond to corruption in evasive or illicit ways (Alam, 1995) than by confronting it directly-reducing their risks and costs in the short run, but playing directly into the hands of corrupt leaders intent upon maintaining their power. Corruption is hardly to blame for all problems in such societies, but there is little doubt that it weakens the ability and will to embark upon improvements.

Thus, where corruption is generally low, it is not just fear of the law that restrains abuses. Much of society is involved in controlling it too. Self-interest sustains the demand for sound institutions, fairness, and accountable government, and social 
sanctions - the widespread condemnation of corruption, and a refusal to see it as acceptable or inevitable - play a role too. This state of affairs cannot be created all of a piece; generally, it emerges through long processes of contention and development, as suggested at the outset.

The Coalitions Strategy. But today's high-corruption countries cannot afford to wait for such outcomes eventually to emerge. The pace of change in the world economy and the harm corruption does to growth (Mauro, 1997) mean that societies with serious corruption become more vulnerable to forces beyond their control, and are missing development opportunities that will not last forever. The challenge is to build an anticorruption force rooted in society, possessing real influence, and sustained by credible incentives - and to build it quickly.

We suggest that social action coalitions are essential to any strategy for broadbased, sustained reform. By social action coalitions we mean self-conscious, freelyorganized, active, and lasting alliances of elites, organizations, and citizens sharing partially overlapping political goals - in this instance, including but not restricted to the control of corruption - and a basic commitment to peaceful reform. ${ }^{1}$ These coalitions unite elites and civil society in a multi-faceted program of reform ${ }^{2}$, deepening and rewarding political will while strengthening civil society. They are distinct from formal party coalitions (Geddes, 1994; Rose-Ackerman, 1999), but are more concrete than mere coordination or consultation groups (Wilson, 1973: 267-68), as they must be able to resolve internal conflicts, redirect members' actions in limited ways, and back up a strategy of action with meaningful incentives not available to outsiders.

Such coalitions - particularly where economic resources are scarce, and where formal organizations are the target constituents - are not easy to build, and may be even more difficult to sustain. At their best, they offer a range of incentives to many different kinds of constituencies and stakeholders. But that is also one of their main problems, for their projects and appeals may conflict with each other, and potential backers' agendas will very likely overlap only partially at best. Circumstances matter, too: if the regime is repressive, openly exploitative, or skilled at using its resources to undermine the coalition and co-opt its members, the most determined efforts may come to naught.

Still, social action coalitions are the best strategy we have for creating a visible, legitimate reform movement quickly, and for mobilizing resources from within a society. They allow reform constituencies to "borrow" size and resources from each other as they work together. Even more important in the long run, the internal incentive systems of coalitions can sustain reform after initial enthusiasm has faded, and can help protect members from reprisals. Particularly critical is their potential for moderating costs and risks for "first movers"—-that is, those who take the first steps against corruption in the

\footnotetext{
${ }^{1}$ On the theory and analysis of coalitions, see Gamson, 1964; Olson and Zeckhauser, 1966; Burgess and Robinson, 1969; Groennings et. al., 1970; Rounds, 1970; and Mahon and Bigelow, 1990.

${ }^{2}$ For studies of coalitions and public participation in reform, see Tendler, 1979; Hede et. al., 1992; Nickson, 1996; Clay, 1997; Klitgaard and Baser, 1997; and Stapenhurst and Kpundeh, 1998.
} 
face of both popular apathy and entrenched opposition from corrupt interests. In a way, we propose to build a "clean machine"-like urban political machines, a broad-based, but unified organization that rewards diverse constituencies for active support. Unlike corrupt machines, however, the coalitions we have in mind are open, honestly managed and aimed at reform.

We believe social action coalitions can, over time, mobilize the kind of broadbased interests and participation found in low-corruption societies. Doing so involves many obstacles, however, and requires us to discuss more than targets, tactics, and good intentions. We focus primarily upon the middle-level question of incentives - that is, what benefits a coalition can offer to supporters - and upon ways of acquiring and deploying incentives sufficient to outweigh the costs and risks of reform. We lay out a typology of incentives, analyze the different constituencies they can attract, and identify important stages in a coalition's development. Then we turn to two contemporary examples of coalition-building, applying our discussion of incentives to each, and identifying strengths and weaknesses in each case. In a final section, we return to questions of strategy, and of assessing progress. The result will not be a coalitionbuilding toolkit, but rather a way of thinking about the strategy that will help reformers understand the opportunities available in all but the most unfavorable of circumstances.

\section{II. "Political Will" and The Role of Civil Society}

Coalitions themselves are not a new idea. Indeed, they are in a way the default option for anyone seeking to jump-start broad-based reform. ${ }^{3}$ Many groups pursue variations on this strategy: the best-known effort is Transparency International, but others such as The Asia Foundation have been involved, and agencies such as the World Bank Institute and USAID have actively aided such efforts. Coalition-building drives often begin with much fanfare, and in some places they thrive; too often, however, they prove difficult to sustain - particularly where they are needed most. Even ardent advocates are likely to agree that we do not know enough about making the transition from launch to long-term viability, or about ways of shifting from leadership-driven initiatives to the selfsustaining, polycentric forces that help check corruption in some societies.

Consider two of the most frequent responses to corruption: calls for "political will" on the part of officials, and for strengthening civil society. Both ideas have obvious merit. Political will — credible, demonstrated, and sustained commitment to reform—is essential to overcoming apathy and outright opposition, to setting clear priorities, and to mobilizing people and resources (see, for Uganda, Ruzindana, 1997). Such leadership can have important demonstration effects: officials who see corrupt colleagues losing jobs and going to jail are more likely to mend their ways than those whose leaders wink at misconduct (or, worse, actively participate in it). Without demonstrated political will, anti-corruption programs become empty gestures, or camouflage for continued abuses.

\footnotetext{
${ }^{3}$ Our thanks to Dr. Emmanuel Gyimah-Boadi for his comments on this point.
} 
A strong civil society - self-organizing cooperative activity at the level between the state and the household - is critical as well (for a variety of studies see Pharr and Putnam, 2000; Putnam, 2000; on the connections between social trust and corruption, see Uslaner, 2001). As elusive as "strengthening civil society" may be in practice, it can provide anti-corruption agencies with critical information and support, uphold a framework of values (Cooter, 1997), provide mutual support activities, build the organizational base and skills citizens need to take on shared problems, and help open alternatives to mistreatment by corrupt officials. Where civil society is comparatively strong, corruption attracts what Weber called "social sanctions"—popular condemnation reinforcing, and often carrying as much weight as, official standards and penalties. Fighting corruption will be lonely, often risky, business, and everyday dealings among citizens, and with officials, may be a game of sauve qui peut.

Political will and a strong civil society can reinforce each other-a pattern seen in many low-corruption countries. Particularly where electoral democracy is viable, civil society can reward leaders and parties demonstrating effective leadership and penalize those who fail. Even where democracy is only partially functional, civil society can still give valuable support to reform-oriented leaders. For their part, such leaders can provide citizens a measure of protection, and open up political and economic alternatives to corrupt exploitation.

But political will is often misunderstood, and a strong civil society seldom emerges simply because it is needed. Neither can be invoked as a deus ex machina: they are outcomes, not inputs, of broad-based political and social changes. Indeed, in lowcorruption societies political will is not just an attribute of particular leaders, but rather is widely shared across the politically active population. Political will is not just a matter of elites' deciding to be good: they must have reason to think that it is in their interests to move against corruption. That is why independent, self-interested groups are so important to reform: those who would abuse power, or acquire it illicitly, must in take the reactions of others into account. Conversely, that is why the "one-man show" scenario of reform so often fails: the will of a strongman can be used for ill, just as easily as for good, and few if any countervailing forces exist in society to check him. As for a strong civil society: we cannot just urge citizens to act. They need leadership, a measure of security, credible prospects that their actions will yield benefits, and an organizational base. They need to know about each other-literally, that they are not alone. These are high thresholds, particularly for those who are vulnerable to corruption because of poverty, powerlessness, and isolation. Where can they, and we, begin?

\section{Minimal Conditions and Basic Strategy}

Social action coalitions will not thrive everywhere. To have any chance of success, they require a functioning state rather the misrule of dictators, private armies or mafias. Leaders must have a genuine intent to govern well - not as easy a test to apply as it may seem - and to serve rather than exploit their societies. A reasonable level of order is also essential; pervasive violence (as in Colombia), famine or disease (as with the African 
AIDS crisis), or social disintegration (as in the Democratic Republic of Congo, or parts of Russia) can render coalition building impossible and corruption a secondary problem. Meaningful boundaries and legitimate linkages between state and society are essential if there are to be working limits on both official power and private influence, as well as the "space" required for a viable civil society and private economy. Where basic civil liberties - freedom to organize, assemble, and voice criticism of the regime (Isham, Kaufmann, and Pritchett, 1996) - and freedom from routine coercion are a reality, people and groups will feel more secure about opposing corruption. Equally important is a reasonably free press; not only can it become a "watchdog", it is also essential to some of the coalition's incentives, as we shall see.

Also useful at the outset, if not essential, is a crisis or opportunity (Wilson, 1973: 275) making action imperative. Hong Kong's famous ICAC-whose anti-corruption strategy included extensive public involvement from the beginning — originated after a corrupt police official's escape touched off mass outrage. Its first step toward winning public confidence was to bring him back to Hong Kong for trial and imprisonment. Outside support from NGOs, aid partners and international organizations, including lawenforcement, pro-democracy and anti-corruption groups, will provide essential resources, expertise, and encouragement. Ultimately, however, opposition to corruption must become the norm - not a response to crisis - and coalitions must become not only selfsustaining but polycentric. Early opportunities will give way to different, but no less difficult, challenges as the coalition matures.

Strategic Questions. Who will be our basic constituencies and stakeholders, how do we attract their sustained support, and what do we ask of them? Virtually everyone suffers from serious corruption, so almost anyone is a potential member. But most costs of corruption, even when they are recognized (and often they are not), are long-term and widely shared; some of the most important costs-lost political opportunities, reduced accountability of government - are intangible or difficult to document. The costs can be most compelling for those who have the least, but for those people the risks of reform are at least as compelling, if not more so. Beneficiaries of corruption, on the other hand, have resources, connections, and a tangible stake in the status quo. Thus many citizens may not feel a compelling reason at any given time to act against corruption at any one time, nor perceive a meaningful chance of success if they did. These are classic problems of collective action: many of the benefits of reduced corruption, such as honest and efficient administration, enhanced political choices, and a more vibrant economy, will benefit everyone if they are realized for anyone. This, together with the costs and risks of backing reform - particularly in early phases - make it tempting to be a free rider (Olson, 1965).

Thus, early recruitment of support should focus on potential stakeholders who suffer immediate and tangible costs of corruption, and have resources they can mobilize against it. Businesses, both small and larger, are obvious candidates, but may be compromised by corrupt linkages of their own. Other constituencies can also be large and potentially important: farmers and stallholders in markets who are subject to police shakedowns, for example. But those constituencies may also be atomized and dispersed 
over large amounts of territory, or may be divided along ideological or communal lines. The best compromise at this level may be to work through existing networks, both at the social level and in more organized segments of politics and the economy, educating people about the costs of corruption while searching for those who find them most oppressive.

Autonomy is a basic issue too (see, for discussions in the context of civil society and non-governmental organizations in Africa, Bratton, 1989, and Bratton, 1994). What sort of relationship should a coalition have with the regime-fighting from the opposition corner, or cooperating? As we shall see below, in our discussion of cases, this is a continuing problem for some coalitions. To some extent the answer depends upon the political options generally available. Where political and administrative leaders are hostile to reform, cooperation may be impossible, and an anti-corruption coalition can be forced into an opposition role. That, clearly, bears real disadvantages: reform in that setting amounts to mobilizing the weak and divided against the strong. Coalition architects may have to play a waiting game, learning and working the social networks and educating possible stakeholders, but holding off on major initiatives until the political climate improves. In a competitive democracy circumstances are much more favorable, but strategy can still be complex: an unrelieved adversarial stance will be counterproductive or dangerous while too little independence will undermine credibility - particularly if one's political allies are found to be compromised themselves. Perhaps the most workable compromise is to remain nonpartisan.

Without doubt, the most important thing is to be forthright about opposing corruption wherever it occurs. But over the longer term a reform coalition must offer officials reasons and incentives to oppose corruption, help them develop the means with which to do so, and reward them for good-faith effort. For that reason, a generally cooperative stance will be desirable wherever it is possible. This will reduce the likelihood of official reprisals, thus helping coalition leaders control strain within the coalition (Wilson, 1973: 30-31) by keeping risks moderate and evenly shared. Ordinarily, the group should not become an investigative body, a whistleblower, or an anticorruption vigilante force. Non-corrupt political leaders will not welcome such disruptions, and may withdraw their support and curtail access to information. Corrupt leaders, or those "on the fence" about reform, will become much more hostile. Similarly, the coalition should resist any temptation to become a certification body: conferring "seals of approval" creates large risks and offers few rewards. Such projects may entail complicated analysis beyond the capacity of coalition members; once given, such approval will be difficult to withdraw. Credit for successes will flow to those being "certified", while the coalition will be seriously damaged should recipients turn out to be corrupt. (And, ultimately, the goal is to develop the capacity of official agencies to practice honest, transparent government on their own, and to encourage journalists and citizens to perform important oversight functions.) Instead, the coalition can help reformoriented politicians locate and unite those both within and without government who oppose corruption, and provide the information, incentives, and mutual support they need to move effectively against it. Efforts to publicize - and to give regime leaders and 
coalition backers the opportunity to take credit for-successes can create incentives to reform now lacking in many high-corruption societies.

\section{Building and Sustaining Social Action Coalitions}

Social action coalitions offer many advantages, but a good idea and the prospective benefits of controlling corruption are not enough. In the medium term, active support of a coalition competes - and, in some respects, can conflict - with members' existing interests and agendas. Organizations - ranging from trade unions to business and professional groups to social organizations without major political programs, all with their own agendas, outlooks, and problems - will be particularly important members, and yet lasting coalitions among organizations are rare (Wilson, 1973: 267). Other participants may have a quasi-organizational base: journalists, for example, may back the coalition as individuals, and yet their effectiveness depends upon their connections with media organizations, and upon the vitality and independence of the latter. For organization leaders there are many reasons not to join a coalition, or to support it in more than perfunctory ways, while the payoffs are small and uncertain. Joining a coalition may be a drain upon scarce resources, and can muddle an organization's identity. Adding a new mission, even as a partner in a broader front, may induce or worsen internal strains (members of a business group, for example, may want honest administration but oppose restrictions on political contributions). Anti-corruption activity may threaten carefully nurtured relationships with government or opposition officials. Autonomy is of particular importance to organizational elites (Ibid., 272-75), and may be seem to be threatened by a substantial commitment to a coalition-the more so as it grows in size and strength. Leaders of formal organizations will likely calculate costs and benefits more ruthlessly than will individuals - after all, the decision may have serious implications for the group, and thus for their own status. Coalition-builders will need to persuade elites that their groups' resources, unity and autonomy will not be threatenedideally, that they will increase in a less corrupt future - and are at risk should corruption go unchecked. This is not to suggest that organizations will never join a coalition; more likely they will give symbolic support but withhold hard resources and public backing in time of controversy. For mass-membership organizations such as women's groups and citizen advocacy organizations, these problems may be less pronounced (Ibid., 203-4): members may press the leadership to support anti-corruption efforts, particularly in the wake of major scandals, and leaders may do so as visible evidence they have taken action. But this assumes that civil society is comparatively strong and free to criticize the regime — conditions that may not apply where corruption is worst.

The Costs of Reform. For both individual and potential organizational allies, reform has real risks and costs. Opposing corruption means taking on powerful interests, often in a framework where institutions and the rule of law are weak. Many people and groups will have been compromised by corruption. Others may have a stake in the status quo, such as a useful friendship with a patron. For them, backing reform can mean foregoing real benefits, or at least a superficial sense of security, in exchange for the uncertain prospect 
of something better - very likely, something widely-shared — at some uncertain point in the future. Particularly for the "first movers" who come out early for reform, these risks and costs can be substantial. A different, but equally problematical, logic applies to "blocking coalitions" (Rose-Ackerman, 1999; De Janvry and Sadoulet, 1989)—those who benefit from the early stages of reform but then seek to prevent further progress. We might imagine a group of businesspeople who, by resisting corruption among government inspectors in their industry, manage to lower their own costs, but then oppose the higher taxes necessary to pursue similar reforms benefiting others.

This does not mean coalition building is futile. Skillful leadership can make the current costs of corruption, and the future benefits of reform, credible and compelling. And we should not underestimate the demonstration effects of finding a few prominent "champions" in both the public and private sectors-people willing to lead the fight, and to show others they are not alone.

The goal is to foster broad-based anti-corruption activity at many levels of society, based upon self-interest and a sense of efficacy, rather than crusades doomed to become noble failures. Reform must eventually take on a life independent of particular leaders' backing, and of the efforts of any one anti-corruption group. A successful anticorruption coalition may, in the long run, fade into the background of the vibrant civil society it helps create (though there will always be need for a group to keep the corruption issue alive). Getting to that point is, of course, a long and challenging process. How can we build this sort of coalition, and what can hold it together over the long run?

\section{What's In It for Me? Thinking about Incentives}

James Q. Wilson, in his classic work Political Organizations (1973), offers an enduring typology of the incentives that motivate and reward organizational participation. He did this by way of challenging the economism of Olson (1965) and others who argued that organizations seeking broadly shared goals would almost inevitably fall prey to "free rider" problems. Wilson, noting that such groups $d o$ form and persist for long periods, and that people act out of diverse motives, reasoned that successful organizations must offer members more than just a chance to achieve a goal. These incentives, he argued, were of four major types (see Wilson, 1973: 33-51):

Material incentives: rewards of tangible value, such as money, goods, or jobs.

Purposive incentives: the accomplishment of a significant goal—often, the formal purpose of the organization. Members of a group that succeeds in cleaning up a city's parks do create a benefit available to all residents, but still derive a special satisfaction flowing from their membership and contribution toward that goal.

Specific solidarity incentives: "...intangible rewards arising out of the act of associating that can be given to, or withheld from, specific individuals. Indeed, their value usually depends on the fact that some persons are excluded from their 
enjoyment (Ibid.: 33-34)". Such incentives include offices, honors, and other recognition; the prestige accruing to a donor who provides a "naming gift" to a university ethics center, for example, would be a large specific solidary incentive.

Collective solidarity incentives: "...intangible rewards created by the act of associating that must be enjoyed by a group if they are to be enjoyed by anyone (Ibid:: 34)", but which (unlike purposive accomplishments) are still restricted to the group itself. These include, for example, the prestige of affiliation; sociability and fellowship; and perhaps a degree of exclusivity.

These types of incentives are useful both for analyzing, and for categorizing, organizations.

Wilson also identifies sub-categories important to our discussion. Material incentives may be exclusive or individual (Ibid.: 36-37). Exclusive material incentives are available to all members, but only to members (the mutual-assistance schemes created by immigrant organizations in 19th-century American cities, or by village associations in African cities today, are examples; so are the discounts on travel or insurance offered by fraternal and professional groups). Individual material incentives are given to some members and withheld from others (and are never offered to outsiders); patronage jobs distributed by a political machine are a classic example. Among purposive organizations, Wilson identifies goal-oriented, ideological, and redemptive organizations (Ibid.: 46-47). The first seek specific changes in their surroundings (e.g., cleaner parks), while the second mount a comprehensive critique of society or of human nature and envision sweeping change (e.g. a new system of property ownership). A redemptive purposive group, which Wilson acknowledges as difficult to define, not only aims to change society but also "...to change its members by requiring them to exemplify in their own lives the new order" (Ibid.: 47). Militant religious sects might fit this category. It is tempting to think of anti-corruption groups as redemptive, but in most instances they are not; in fact, redemptive groups face special problems. Many end up walling themselves off from the societies they seek to redeem, rather than building a broad base for action, while others fall prey to internal disputes over what the redemptive cause requires of people in practice.

What Can Incentives Do? The most obvious incentives for an anti-corruption coalition are purposive: the goal, after all, is better politics and administration. But most organizations use diverse, overlapping incentives aimed at multiple constituencies - and that is likely to be particularly true of a social action coalition. The broader its agenda and the more segments of civil society it seeks to mobilize, the truer this will be. A social action coalition must be many things to many people and groups; it cannot be effective simply by proclaiming a noble purpose, or by bombarding a problem with good ideas. At the same time, different sorts of incentives serve different purposes and, as we shall see, become critical at different phases in the coalition's life cycle.

Two incentive problems arise immediately. First—and particularly where corruption is worst - reformers will have few material resources with which to sustain 
themselves, much less to offer to others, and yet the material enticements of corruption are all too familiar. Second, the agenda may seem risky and unlikely to succeed, and thus purposive incentives may not be credible.

The first problem will be familiar to anyone who has ever belonged to an organization - particularly to those who have watched a group become so consumed with fund-raising that it loses sight of its original purposes. But it has other ramifications as well. One reason reformers might lack material resources is that corrupt interests can monopolize opportunities within an economy that is unlikely to be robust to begin with. Many businesses and individuals will deal with corrupt officials and their clientsresponding to corruption illicitly, in Alam's (1995) terms - or tolerate and avoid them (responding evasively), because they perceive few alternatives. Joining an anti-corruption coalition thus means taking on risks and costs - losing the few corrupt benefits one now receives, as well as taking on new uncertainties. Initially at least, the coalition may offer little compensation.

Thus arises the second problem: while reduced corruption would bring substantial benefits, those are long-term prospects at best. An incentive system based mostly on purposive appeals thus is "fragile": it is open to conflict over strategy and tactics and vulnerable to outside events. An election result, changed economic circumstances, or the rise of some hotter new issue, for example, can weaken the appeal of purposive incentives dramatically. An anti-corruption agenda in particular may seem goal-oriented to some and redemptive to others, with conflict the likely result. Wilson argues that purposive incentives must be relatively non-controversial (Wilson, 1973: 43). Causes rather than issues, and cooperation rather than conflict, will be essential if the coalition is to avoid threatening the interests of its own members (and thus the autonomy of organizational members) and antagonizing the regime. Work will consist, not of the sorts of crusades and condemnations likely to keep a mass constituency aroused, but rather of discrete tasks - raising auditing standards, for example, cutting down the number of steps in routine bureaucratic functions, or building information networks. These, in turn, will require staff and leadership with considerable sophistication and staying power-and such a staff will need to be paid.

Purposive incentives thus must be supplemented by others that will attract the support of people and groups able to contribute funds and other scarce resources. Specific solidary incentives (Ibid., 208-210) can be crucial in this regard. They can be targeted to particular members and benefactors: offices, honors and citations, and exclusive access to information, can motivate support for the coalition. The staff salaries and resources noted above also fall into this category; purposive appeals might launch the coalition, but solidary resources are critical in sustaining it. Collective solidary incentives, such as sociability, prestige and a sense of mutual support, are also valuable, particularly where civil society is weak. Such appeals - notably, prestige-require an "audience" in order to be effective (Ibid.: 40): leaders may hand out all manner of "Corruption-Fighter" awards, for example, but if no one hears of them they are of little value. A relatively free press is an essential partner in making these incentives work. 
Unlike corrupt political machines, social action coalitions are unlikely to possess extensive individual material incentives; if available at all they may create internal contention. They can also be deployed from without, in manipulative and divisive ways, by corrupt officials and their cronies. But a coalition can provide exclusive material incentives - things of real value, perhaps created by the coalition's own efforts, that can be restricted to members only. Access can be controlled, and converted into support for the coalition, by insisting upon contributions or labor from members. In New York City, for example, teams in a youth soccer organization were recently given preferential access to a City-owned playing field after they worked on renewing its facilities. In a crowded city access to such facilities is of real value, even if it does not make individuals wealthier. The immigrant savings and mutual-aid groups noted above were founded in difficult circumstances by poor people, but nonetheless pooled small individual contributions to provide valuable aid available only to members. An anti-corruption coalition could emulate this model by setting up a kind of "corruption insurance" scheme in which members pool information and resources, and make binding pacts not to pay bribes. Such pacts could reduce the risks flowing both from corruption itself, and from coalition membership, and through mutual aid reduce the costs of corrupt pressures that cannot be avoided. This idea will be discussed in more detail below.

What might the overall incentive system of an anti-corruption coalition look like, and which incentives would appeal to what members and constituents? The following table offers some general ideas: 
Coalition-Building Incentives,

By Type and Target Constituency

(categories drawn from Wilson, 1973)

\begin{tabular}{|c|c|c|}
\hline \multicolumn{2}{|c|}{ MATERIAL } & \multirow[t]{2}{*}{ SPECIFIC SOLIDARY } \\
\hline Exclusive & Individual & \\
\hline $\begin{array}{l}\text { "Corruption } \\
\text { Insurance" }\end{array}$ & $\begin{array}{l}\text { Econ benefits } \\
\text { of improved } \\
\text { economy }\end{array}$ & $\begin{array}{l}\text { Data/information banks } \\
\text { - on corrupt agencies, } \\
\text { officials } \\
\text {-on best practices }\end{array}$ \\
\hline $\begin{array}{l}\text { Information } \\
\text {-vulnerability } \\
\text { assessments }\end{array}$ & $\begin{array}{l}\text { Security from } \\
\text { better } \\
\text { governance }\end{array}$ & Research products \\
\hline $\begin{array}{l}\text {-prevention } \\
\text { within orgs } \\
\text {-legal and tech- } \\
\text { nical advice }\end{array}$ & & Rewards, recognition \\
\hline \multicolumn{3}{|c|}{ Prime constituencies: } \\
\hline $\begin{array}{l}\text { Small firms, } \\
\text { domestic } \\
\text { entrepreneurs } \\
\text { and investors }\end{array}$ & $\begin{array}{l}\text { Citizens } \\
\text { generally } \\
\text { Civil society, } \\
\text { NGOs }\end{array}$ & $\begin{array}{l}\text { Professional coalition } \\
\text { staff, researchers } \\
\text { Benefactors, financial } \\
\text { supporters } \\
\text { Anti-corruption } \\
\text { "champions" }\end{array}$ \\
\hline
\end{tabular}

\section{COLLECTIVE SOLIDARY}

Prestige, improved image -domestically, internationally

Enhanced autonomy for organizations, press, opposition leaders, civil society groups

Sociability, fellowship, mutual encouragement

Mass membership

Journalists

NGO leaders

Government elites

\section{PURPOSIVE}

Goal-Oriented*

Reform as public good

\section{Better governance}

Fair political, economic processes; social equity

Stronger economic, social institutions

Enhanced Rule of Law

Mass membership

NGOs

Aid/lending partners

Democracy groups and supporters

\footnotetext{
* Ideological and Redemptive sub-types of purposes not recommended
} 
The "Clean Machine": Putting Incentive Systems to Work. The table above gives only a general illustration of the range of incentives available to a social action coalition seeking to supplement purposive appeals. Even though it may lack the kinds of individual material incentives available to corrupt politicians and bureaucrats, such a coalition can offer many other things to a variety of constituencies - and indeed must do so.

Of these, exclusive material and specific solidary incentives may be the least familiar. They will, however, be the most effective at attracting sustained support from small to medium business firms, domestic entrepreneurs, and investors - precisely those to whom a coalition must turn for material resources. Information can be of real value. It may take the form of technical assistance: vulnerability assessments focusing upon corruption risks within or from outside a firm could be performed for active coalition backers. Training programs, advice on auditing requirements and internal control systems, and a data bank on best practices or risk assessments elsewhere can be of real value. Whether these services be provided on a fee-per-use basis, or made available to members paying a regular subscription — the preferred option — they are reasons to join and support a coalition, to maintain it as a main point of reference for those concerned about corruption, and to demonstrate the effectiveness of paid staff. Recognition is a similar incentive: coalition leaders should spare no efforts in giving awards, citations, and favorable publicity to key backers as well as to anti-corruption "champions" in government - but of course, must target them carefully so as to minimize risks of future embarrassments should those recognized turn out to have something to hide.

Other benefits consist of offsetting the costs of corruption itself. The "corruption insurance" proposed above might take several forms: technical assistance, pooling funds for legal assistance and partial compensation of those hurt most by corrupt demands, and active support for whistleblowers are just a few examples. At another level, the coalition could broker integrity pacts among firms in a sector of industry, or among bidders for large contracts, as exemplified by Transparency International's "Islands of Integrity" initiatives. These can create confidence that refusing to pay bribes does not mean that one is not just handing advantages to competitors; pledges could be given added weight by requiring bidders to post a small deposit, to be forfeited if they do engage in corruption. Some of these services could be offered to government officials, though care must be taken, particularly in the early phases, not to antagonize the superiors to whom they report. In both the private and public sectors, such activities can provide a focal pointand a measure of strength in numbers - for those who wish to abstain from corrupt dealings but have felt isolated in the past.

With its base in both sectors, the coalition can also monitor and report publicly on privatization and deregulation schemes, civil service reforms, plans for devolution and decentralization of official functions, and campaigns for improved administrative controls. As noted above, however, the goal is not to demonstrate the absence of corruption. That remains the responsibility of public officials, auditors, and oversight bodies. The coalition's role is to help them take credit for successes while ensuring that failures will not go unnoticed. In effect these are steps toward rewarding, and broadening the base of, political will, while strengthening the role of civil society. 
Collective solidary incentives - sociability, prestige - may seem an afterthought, or even a luxury, but in fact they will be essential to maintaining mass support, and with it the coalition's visibility and legitimacy. It is no accident that the Hong Kong ICAC's highly regarded public education campaigns have long included a component of fun and social activity, particularly for young people. For journalists, honest contractors and officials, and the leaders of participating organizations, a kind of security can flow from membership: those who conceal corruption or practice intimidation may think twice if they know their critics are backed by a larger group. Conversely, coalition members tempted by offers of money for silence, for example, have something important to lose if they are found out - membership of a prestigious and visible group. Such incentives may be difficult to quantify, but they show how a solid coalition can, through aggressive use of multiple sorts of incentives, alter the calculus of corruption and reform.

\section{Getting Started: Stages of Coalition-Building}

Both the targets and tactics of anti-corruption efforts, and the development of the coalition itself, will be influenced by the character of the society within which they are launched. The state, trajectory, and sources of economic development; the degree of democratization, and quality of institutions and political competition; legitimacy of government and nature of a country's communal and political culture(s); and its international situation will all be major considerations. Moreover, virtually all of the factors in that list have important historical dimensions that will vary from case to case, and that will shape current problems and options in critical ways. That list could be made much longer; a full consideration of such factors lies well beyond the scope of this analysis, though clearly we will be able to learn more about them to the extent that we study coalition building comparatively.

We can, however, outline general stages in the coalition-building process. Doing so helps us both to specify specific major tasks that must be addressed at each stage, and to understand how incentives must be created and deployed. The result is not a coalitionbuilding toolkit — such would be of doubtful value given the variations noted above - but rather a rough guide to setting priorities and assessing progress as the process unfolds.

The table on the following page presents one approach to sequencing. ${ }^{4}$ Four stages are identified: formation, in which the core of a coalition is organized, early leaders and "champions" are identified, and an agenda takes shape; credibility, in which the coalition demonstrates that it can act effectively and it is thus worthy of support from a variety of stakeholders and constituencies; expansion, a particularly critical stage in which a small organization builds a broader social and resource base while retaining coherence and effectiveness; and finally, transformation, during which the coalition does not so much grow as become polycentric, taking initiatives on many fronts and drawing strength from many sources. During that last stage, in effect, it realizes the goal of combining broad-based political will with the protean qualities of a strong civil society.

\footnotetext{
${ }^{4}$ We thank . Soji Apampa for his very thoughtful and detailed comments on this and other points.
} 


\section{Stages of Coalition Evolution}

1. Formation

Taking initiative; cooperation

Agenda-setting

- corruption as an issue

— early targets and tactics

2. Credibility

$$
\begin{aligned}
& \text { Early success; giving/ } \\
& \text { taking credit } \\
& \text { Identifying/linking to } \\
& \text { social networks; } \\
& \text { Articulating a future } \\
& \text { Finding resources; Publicity }
\end{aligned}
$$

3. Expansion

$$
\begin{aligned}
& \text { Extending networks } \\
& \text { Identify backers, stakeholders } \\
& \text { Building core staff, expertise } \\
& \text { Sharing information } \\
& \text { —on coalition's activities } \\
& \text { —on techniques }
\end{aligned}
$$

4. Transformation

Polycentric action, agendas

Diffusion, institutionalization of political will

Empowerment of stakeholders, civil society

Counteracting costs and risks of corruption
Anti-corruption

"champions"

"Champions"
Networks
— social
- organizational
- official

\section{Early Coalition}

- leaders

— extended networks

Mature Coalition

- overall coordination

—dispersed leadership

— extended network
Purposive

Purposive

Collective solidary
Specific solidary

Collective solidary

Purposive

(note shifting

incentives in this

phase!)

Purposive

Specific solidary

Exclusive material

Collective solidary

Notes: Most tasks carry over to later stages, and in a Mature Coalition are delegated across a dispersed

leadership; Incentives are listed in rough order of emphasis during a given phase 
These stages will not necessarily be sharply demarcated in practice. Indeed, to some extent later stages subsume earlier ones without supplanting them. Still, identifying these stages may be useful not only for setting priorities, but also for anticipating problems, needs, and sources of support, and for understanding emergent stresses within the coalition and responding to them appropriately.

The most important changes from one phase to the next have at least as much to do with enhancing - and sustaining - the complexity of the coalition, its repertoire of incentives, its constituency base, and its agenda, as with increasing size. A newlylaunched anti-corruption coalition that deploys only purposive incentives and seeks only to expand will, in the long run, be able to do neither: purposive incentives alone will not help it grow, and without growing it is unlikely to acquire the resources to accomplish its purposes. The incentive system must become more elaborate, attracting new kinds of supporters and addressing the corruption problems that concern them; at the same time the coalition must demonstrate credibility - that it is worthy of support and that the future it envisions is not only desirable but achievable.

For this reason growth per se may be a third-stage priority. More important, early on, will be identifying "leaders and champions" in both the public and private sectors, building cooperative relationships among them, and then moving on to some visible early successes. Those, as Klitgaard et. al. (2000) point out, should not necessarily be the most serious corruption problems in a society; attacking those may guarantee defeat. Instead, they argue for "picking the low-hanging fruit"—-that is, making sure the early struggles are won. Such successes, well publicized, are essential to building support and winning resources. In this same connection, reformers are typically told to "fry a big fish" - that is, to arrest, and convict or oust, a prominent corruption ringleader. This is undoubtedly good advice in principle, and can be a major step toward breaking officials' sense of impunity. But "big fish" have big friends, as well as enemies; coalition leaders must move carefully, for their credibility in the eyes of civil society may be much more doubtful. They must be absolutely certain that their cooperative relationship with regime leadership is genuine and strong enough to withstand considerable controversy. Once a variety of early victories have been notched up, and after the fish fry has ended, a coalition can possess considerable prestige that can be parlayed into solidary incentives.

Early growth may be best pursued by working within established social and political networks; later on, those can be expanded much further into civil society. The transition from winning credibility to expansion may seem relatively simple, but in fact this transition is trickiest of all: the resource requirements of expansion, and the internal stresses of attaining it, must not be allowed to weaken leadership, coherence, and credibility. Making that more difficult is the fact that as long as growth is a goal in itself (and at some point in the coalition's development, it must be so), purposive incentives may have to take a back seat to others that draw constituencies into the group - most likely, specific and collective solidary. This is not to imply that purposes are unimportant in this phase; indeed, they cannot be obscured, or else the coalition will fall into the trap of "goal displacement" - that is, a kind of limbo in which organizational maintenance supplants longer-term goals, to the detriment of both. One way to prevent this is to 
remember that expansion is a means, not an end in itself, and that that at some point that stage must end. Growth, for its own sake, has diminishing returns.

The final stage is that of a fully developed coalition sustaining itself while acting on many fronts. Initiative passes from core leadership to many centers of activity. And here, the incentive system is most complex of all, reflecting that polycentric pattern of action. In this stage the coalition ceases to follow any one tactical or structural plan; perhaps its boundaries and overall coherence become very difficult to pin down, and change considerably over time. But at that point, it will have succeeded in creating the kind of broad-based activity - sometimes contentious, and always sustained by selfinterest - that we emphasized at the beginning. It is unlikely that the coalition will put itself out of business, for corruption will never be completely eradicated, and a group monitoring and publicizing the problem will always be needed. Perhaps that group will in the end resemble the leaders-and-champions pattern of stage one. But the critical difference will be that it will be backed up by the broad-based array of interests and social forces that it has assembled, and set in motion, against corruption.

The table just above leaves out an obvious and critical dimension of such action: that is, how, specifically, to attack corruption itself? That question and a consideration of some contemporary examples of coalition building are the focus of Part II. The emphasis will not be on the changes needed to control corruption, but rather upon what a coalition can do to ensure that those who govern understand and push for those changes.

\section{PART II: COALITIONS IN ACTION}

\section{What Should a Coalition Do?}

At the outset we suggested that social action coalitions can reinforce, and interlink, political will and the vitality of civil society. What does this mean in practice?

Strengthening Political Will. While political, administrative and judicial officials bear much of the burden of reform, a strong coalition can support, and reward, their will to see it through. Simply put, the coalition's support can persuade elites that they have an interest in reform, via popularity, enhanced development, a better international image, or simply their own political standing. Civil society can become a full partner, diffusing the will to reform through much of society, and leaders can benefit from the backing of those interests and groups, as long as they earn it. This entails supporting elites politically and socially when they do pursue reform - a task that may not be easy where corruption has become entrenched - while making it clear that those leaders do not own the coalition or the corruption issue in the long term. Ultimately, the only reliable index of political will is results: credible anti-corruption action that is sustained over time and in the face of whatever opposition emerges. 
A coalition with a strong grassroots base can also identify the sorts of reform targets that will be seen as most important_-advice that committed reform leaders will value greatly. Then, in part through its contacts with journalists and organizations in civil society, it can aid them in taking credit for reform successes, while making sure that failure to act is difficult to conceal. It can also provide valuable information on the ways counterparts elsewhere have dealt with the problem. Links to opposition leaders-where such are not dangerous - are a touchy issue here: if they are too weak, reformers may be seen as "front men" for the regime, and will pay a price in terms of credibility; but if they are too close there may be little access to officials and information in government. The key is to cooperate with the regime while remaining open and independent, making it clear that the coalition has room for all who oppose corruption.

A coalition in a position to mobilize popular disapproval can also convey pointed political messages. Careful judgment is in order once again: cooperative ties with the regime are ordinarily valuable assets. Moreover, if coalition managers too frequently condemn failures without pointing to successes, followers decide that reform is futile. And as a practical matter, in some of the most corrupt societies popular opinion is of little significance; those who express disapproval may take significant risks only to be drowned out by cheerleaders for the regime. Still, targeted expressions of disapproval (e.g. the Sierra Club's "Dirty Dozen" lists of U.S. Congress members) may demonstrate that disregarding anti-corruption views has real costs while underlining the movement's independence.

Building a Stronger Civil Society. A strong civil society can develop, protect, and express important social values, and giving people and groups the "space" and security they need to resist corruption. Likewise, it can encourage and protect direct, rather than evasive or illicit responses to corruption (Alam, 1995), and open up political and economic alternatives to abuse by corrupt officials and their clients. In this way, a strong civil society can reduce the costs of corruption and the risks of opposing it directly. With such alternatives available, the short-term rewards of corruption become less tempting, the longer-term and shared costs become more clear, and the incentives to control it become more compelling.

Over the long run, a viable civil society becomes a force for accountability in all but the most repressive societies. It does so through the broad mobilization of many proreform interests, becoming the vehicle through which support for political will is most strongly conveyed. Political leaders, in turn, have more reasons to move credibly against corruption - even in undemocratic systems, or in democracies where political competition is weak - because doing so can build legitimacy for the regime.

\section{$\underline{\text { Public Education }}$}

Some of the most important things a coalition can do in civil society involve changing the ways people think about corruption. Many of its costs are known to all: money lost in bribe payments, time lost in dealing with corrupt officials, and opportunities lost to bribe-paying competitors are part of a long and familiar list. What 
may be less well understood are the long-term, shared, and intangible costs, such as delayed and distorted development, the loss of political choices and accountability, and the mutual suspicion that corrodes business, political, and personal relationships. The task is to show people how corruption is involved in many of their own problems-both dayto-day, and over the longer term. Some of these ideas will be less than obvious, for they are measured in terms of values, security, and opportunities that citizens have never possessed, and which they may believe they will never enjoy.

For that last reason it is important to break the sense that there is nothing that can be done. More citizens might resist paying up or concealing illicit deals, and many officials might "blow the whistle" and support reform, if they know they are not alone. They will also know the risks - and, the coalition must be frank about them: reporting corruption or resisting corrupt demands often means an uneven fight with powerful officials and their cronies. Those who have paid or taken corrupt payments in the past may fear, with good reason, that those dealings will be used as evidence against them by more powerful figures. The answer, in part, is to lengthen the time horizon - to encourage people to look beyond the short-term giving and getting toward the long-term consequences of corruption for themselves and for society. The Hong Kong example suggests that sustained public education can succeed in changing attitudes at a basic level.

At the same time, information sharing has its pitfalls. The process may become an echo chamber in which things "everyone knows" acquires a spurious authority through repetition. Reform is reduced to slogans, as has already happened, to a distressing degree, with terms like "political will" and "civil society". A one-size-fits-all understanding of what corruption is, and of what remedies must be pursued, can result: already, we too often see "corruption" treated as a synonym for "bribery", and essentially as a problem in the liberalization of international trade (Johnston, 2002). When this happens, local knowledge and experience are devalued and reforms reflecting local realities are less likely to emerge.

For this reason, a social action coalition should develop research and analysis capabilities if at all possible. These need not be elaborate to be valuable. The tasks can be shared among coalition officials, journalists, and academicians, for example, and indeed where the political situation is uncertain they may be easier to sustain if they are delegated in that way. Research and analysis enable a coalition not only to work hard against corruption, but to be smart about it — providing convincing advice and feedback to elites about corruption problems and the ways they are perceived, and to citizens about the progress of reform. Perhaps most important, a social action coalition with at least a basic research capability will be much less dependent upon official reports and statistics. It will also serve as an independent source for those, within and without a given society, who want to know more about the corruption problems there. That, in turn, may be one of the most important early ways to earn credibility, and later on can be a source of valuable exclusive material incentives. Sharing such knowledge is also a way to protect "institutional memory" in less-secure settings. 
Finally, an honest public education strategy will include the lesson that reform is costly, requires sustained support and vigilance, and will be marked by many reverses and crises. In fact, coalition initiatives may create an impression that corruption is on the increase, as cases become public knowledge and critics of corruption become more aggressive. Coalition leaders must do all they can to give the public a realistic picture of the likely consequences of reform, lest disillusionment set in. American campaignfinance reform advocates in the 1970s, for example, largely failed to do this, with the result that disclosure requirements created an erroneous perception that the political process was suddenly up for sale. The promised new age of clean politics never quite materialized. As a result, advocates of new reforms now find the public's response is heavily tinged by cynicism.

\section{Two Cases}

Our analysis of incentives is not offered as a one-size-fits-all coalition strategy, but rather is aimed at helping leaders adapt to particular circumstances and constituencies.

Similarly, no single case can illustrate all of the practical complexities of the social action coalition approach. Moreover, actual cases present us with moving targets: what is true at one point may not hold later on. Still, let us consider two cases - the relatively new Ghana Anti-Corruption Coalition, and the Bangalore Agenda Task Force in that Indian city, an initiative whose origins date back nearly a decade. Both illustrate the challenges facing coalition architects, and both can point to possibilities for action. At the very least, thinking about these two cases may make it clearer how our main schema applies (or falls short) in other specific cases.

The Ghana Anti-Corruption Coalition. The Ghana Anti-Corruption Coalition (GACC) was founded after the $9^{\text {th }}$ International Anti-Corruption Conference in Durban, South Africa, in October, 1999, by a cross-sectoral grouping of Government officials, official anti-corruption agencies, and civil society. It merges a variety of anti-corruption initiatives launched in 1998 when the Commission for Human Rights and Administrative Justice organized the first National Integrity Workshop. GACC's goal is to mold a diverse range of official and private-sector interests into a coalition, working wherever possible with international business, civil society, the news media and religious bodies. It grows out of a widely recognized need for a more structured relationship between and among local and international anti-corruption initiatives, and for ways of "deepening" the social roots of reform. The World Bank Institute's core course, "Controlling Corruption: An Integrated Approach", first piloted in June, 1999 to a diverse group of stakeholders from seven countries (Ghana, Uganda, Kenya, Tanzania, Benin, Malawi, and Ethiopia), was a catalyst underscoring the potency of participatory approaches to corruption control.

The initial Ghanaian participants included the Serious Fraud Office (SFO), the Commission on Human Rights and Administrative Justice (CHRAJ), and the Institute of Economic Affairs. The group has since expanded to include the Private Enterprise Foundation, the Center for Democratic Development (CDD), and the National Institutional Renewal Program, an office directly under the Presidency in charge of Ghana's public sector reform agenda. The Ghana Journalists Association represents the 
news media. On the civil society side, a particularly important component is the Ghana Integrity Initiative, the local chapter of Transparency International. It brings together a variety of organizations, religious groups, media representatives, legal practitioners and individuals committed to reform.

The question of how much, and how best, to coordinate activities with the government is a complex one in Ghana. The new Government has indicated they do not intend to nominate anyone to GACC but will negotiate a framework for liaison with the Coalition, either through the Attorney General or the Office of Accountability. Still, the Coalition has asked the Chairman of the Public Accounts Committee to become a partner, and has made similar approaches to the Auditor General. Former President Jerry Rawlings did, however, approve the coalition's request for a World Bank diagnostic survey on corruption. This survey was conducted by the CDD from March to July, 2000, with additional support from the United Kingdom's Department for International Development, the Canadian International Development Association, and the United Nations Development Program. These agencies have also agreed to assist GACC with post-survey analyses, dissemination of findings, and the formulation of specific policy proposals.

The GACC agenda offers an ambitious set of purposive incentives, including:

- Creating a forum for interaction among the three arms of government, public and private sector institutions, and civil society groups to work on anti-corruption strategies

- Encouraging the exchange of information and joint sponsorship of programs, where appropriate, to achieve effective utilization of resources

- Enhancing transparency and reducing opportunities for corruption in government, public and private institutions, and civil society organizations

- Sponsoring initiatives leading to appropriate legal and institutional reforms

- Strengthening the capacity of its constituent organizations and other anti-corruption bodies where necessary

- Serving as the primary organization for the implementation of Ghana's anti-corruption plan

Projects contributing to those goals have included, first and foremost, the diagnostic survey mentioned above; in addition, GACC has prepared an action plan that will serve as the basis for national debate and consensus building. Coalition members are pushing for freedom of information and whistle-blower protection legislation, and efforts continue to strengthen working relationships among public agencies, the private sector and civil society. 
Coalition building on this scale is unprecedented in Ghana, at least with respect to corruption issues. Moreover, GACC sees its efforts as differing from previous attempts at reform because they are based upon collective action and common ownership of the corruption issue by all stakeholders, emphasize sustained and coordinated action, and seek both to build synergy and eliminate duplication. GACC proposals are to be integrated with broader public-sector reforms with the goal of creating a national integrity system supporting strong and open decision-making procedures. Such goals, and the diverse membership of GACC, both reflect the essence and reveal the difficulties of the coalition strategy; a critical question will be GACC's success in backing up this ambitious purposive agenda with other incentives strong and diverse enough to sustain it.

Thus, GACC will face serious sustainability and credibility problems. Scarcity of key resources will threaten the effectiveness of the organization. GACC's total reliance upon foreign donors will raise questions about commitment to address the problem from within. The new Government's plans for an Office of Accountability, anchored in the President's office and serving as the official focal point for corruption issues, is a hopeful sign, as is the Government's offer of liaison through the office of the Attorney General and Minister of Justice. But where does this leave both CHRAJ and SFO, the two organizations that have the mandate to address problems of corruption and fraud in addition to other issues, and two "core members" of the coalition? The future roles, and resources, given to those bodies will be a critical test of Government commitment to them, and to GACC, as will the Government's willingness to back GACC publicly and provide funds for its operation.

Another issue central to GACC's repertoire of purposive incentives is the problem of setting an agenda. Although the coalition was formed as a result of the World Bank Institute's Core Course, a clear-cut and manageable agenda still has yet to emerge. The coalition currently has no structure other than a category of "Core Members" (the participants identified above), a Secretary, and a Spokesperson. The core group has so far successfully supervised the execution and release of the diagnostic survey, proposed an action plan, and has conducted a national workshop (as well as two regional workshops in Tamale and Kumasi) to disseminate survey findings and seek input from citizens. However, coalition members have indicated there are no clear definitions of roles, which leaves them constantly engaged in "negotiations" to reach binding agreement. The current action plan reflects this mode of operation, and the coalition still needs to move to the stage of establishing credibility through early successes. While the goal of collegiality and collective ownership is laudable in many ways, the current fragmented structure and tactics of repeated internal negotiation may, in the long run, mean the agenda will always be ad hoc and unfocused, and will make the provision of solidary, as well as specific material, incentives difficult if not impossible. GACC must provide such incentives, and must clearly define the roles of various institutional members, in order to prevent distrust from brewing among its members, and to ease reliance upon purposive appeals.

One could argue that some of the core members, such as CHRAJ and SFO, would have purposive reasons to support a strong GACC because of their current institutional 
mandates, and that they would be better able to build leverage for some of their work through the coalition. This may well be so, though it may also be the case that such support raises questions of autonomy and resource allocation within those two bureaucracies. In any event, such clear purposive incentives are weaker for other members who do not have an anti-corruption mandate as part of their daily work. What realistic promise does GACC hold for groups such as the Private Enterprise Foundation $(\mathrm{PEF})$ ? Can research institutes such as the Center for Democratic Development (CDD), or Institute for Economic Affairs (IEA), be expected to conduct research without compensation because they are part of the coalition? How can GACC keep coalition membership from being and all-cost, no-benefit proposition? Can specific solidary incentives be a workable substitute, and are our "corruption insurance" ideas likely to prove workable? A key first step to resolving some of these issues is transparency. GACC rules, operations, and the roles of its core members must clear to all.

Supplementing diffuse purposive appeals with a more elaborate and sustainable system of incentives, however, seems an urgent challenge in GACC's case.

Representation also is a major challenge for the GACC. Should its "core members" be restricted to top leadership of various institutions? Should those institutions not be able to send representatives to meetings where concrete decisions are made? Again, that presupposes clear roles and agendas. But GACC has not been operating in that way; meetings have been postponed and decisions have not been taken because some top Executive or Core member is away and cannot attend the meeting.

GACC seems likely to face a real struggle to survive its infancy unless some of the above problems are resolved in a transparent manner. Donors may become skeptical about the credibility of the coalition and tie their promised support to the resolution of these issues. Coordination with Government is similarly endangered. The coalition is very much aware of that difficulty, at least, and concrete steps are planned. In a recent resolution agreed to at the end of a National Anti-Corruption Workshop organized by the GACC in June, 2001 (which was attended by some Government Ministers), the participants called on government to demonstrate commitment to the Action plan by funding its programs, as well as overwhelmingly agreeing to a re-designation of the Action plan as the "National Anti-Corruption Action Plan".

Other immediate needs include efforts to educate the Executive, and to persuade it to review the partnership approach; to link anti-corruption measures to broader governance programs; and to rationalize public ethics infrastructure. Expanded civil society and private sector involvement are also planned, as ways to stimulate demands for accountability. A recent strategic focus statement released by the GACC proposes a series of formal and informal interactions, as well as publications to disseminate information, all aimed at stimulating broader discussion and a multi-stakeholder ownership of the Action Plan. Core members will act as a steering committee to develop a second tier of civil society bodies, private sector organizations and traditional authorities with a national character, and a third tier of community-based organizations at the district level. Finally, GACC plans to strengthen its capacity to ensure effective coordination of the coalition-building process, emphasizing joint monitoring and 
performance evaluation through a Sub-Committee of the Mini Consultative Group meeting on Ghana yearly.

No one would dispute the notion that anti-corruption activity in Ghana is a daunting prospect. Any observer must respect the fact that GACC is a coalition-building effort without precedent in that society. Still, GACC continues to grapple with significant Formation-stage problems. The Credibility phase-perhaps the most difficult of our four-still looms as a major challenge. Success at that phase will require a more diverse and sustainable set of incentives that those available thus far. The autonomy issue remains very much unresolved: GACC seems at times to be both ignored by government and hamstrung by it. Success at the Expansion stage will require not just growth, but also an extension of GACC beyond its current urban/elite composition: without significant participation reaching deep into civil society and out into rural areas, it may remain a small advocacy group that is easily co-opted or ignored by the regime. Thus, GACC represents both an essential beginning, and a useful illustration of the difficulties of coalition-building for the long term.

Bangalore, India. Bangalore, with a population around 6 million, is India's fifthlargest city, and is capital of the state of Karnataka. Located in the South about midway between the two coasts, it has long been a center for managerial and technical education, and in recent years has become a focus of India's burgeoning computer software industry.

In 1993, Marketing and Business Associates (MBA) Ltd., a leading market research agency based in Bangalore, began gathering survey data, informant interviews and statistical indicators focused upon the performance of local government. This project was aided by funding from the World Bank Research Support Budget. The data were compiled into "report cards" assessing the quality of a variety of city government services. ${ }^{5}$ Corruption was just one criterion for evaluation, but the results were striking: extensive bribery and demands for payments were reported, along with waste and inefficiency. One estimate had it that the overall cost of bribery "exceeded the entire municipal budget by a factor of seven" (Klitgaard et. al., 2000: 61). These results drew extensive attention and debate within local government, in the press, and among the public at large.

One result was that three years later a second series of report cards were drawn up to assess trends. It was decided that prior to public disclosure, senior officials of the major public agencies covered in the second round should discuss the findings. A mini report was prepared for each agency, highlighting the key indicators of service quality, public satisfaction and other pertinent dimensions. Major service providers listened to the citizens' reactions, examined their organizations' performance, and considered ways to improve responsiveness. More important, all the public agency heads involved in the report, without exception, commended the initiative and acknowledged the value of popular feedback.

\footnotetext{
${ }^{5}$ Adapted from Samuel Paul, "Nudging the State to Act: What Report Cards Did in Bangalore", 1999; see also Klitgaard, Mclean-Abaroa, and Parris, 2000; and Paul, 1995.
} 
A new Chief Minister of Karnataka took office around the time the second report card was released. He made a public commitment to improve state governance, and in particular to upgrade local infrastructure and services. He established the Bangalore Agenda Task Force (BATF), consisting of prominent citizens, with a mission of getting industry and civil society more involved in the city's rejuvenation. This was the first time that the state's chief executive had openly responded to demands of the citizens, the media, and public interest groups to increase city service providers' accountability. A major public event - "The Bangalore Summit"-followed; in addition to pledges of improvement from the heads of public agencies, industrialists and businesspersons made public commitments of funds to improve or develop specific public activities or infrastructure.

BATF has regularly met with all the service providers to track the progress of the program action plan. The initiative has demonstrated some "quick wins", such as developing a system for the self-assessment of property taxes. Rather than relying on tax collectors, who traditionally have levied property taxes arbitrarily and taken advantage of the citizenry, the new system has easy-to-follow, verifiable criteria that citizens can apply themselves. Grievance procedures are also open and clearly defined. Information has been disseminated through meetings in different parts of the city, held in cooperation with citizen groups and other NGOs.

Controlling corruption and improving services at the local level are tasks on a different magnitude than those undertaken in Ghana. But the Bangalore case illustrates precisely the sort of reinforcing links between civil society and the political will of major leadership that coalitions may be best positioned to build. Another important factor was the way corruption, and responses to it, were incorporated into broader assessments of the efficiency and responsiveness of local agencies. In many instances, responsive leadership and a streamlined administrative process may be among the most effective anticorruption strategies available (Klitgaard et. al., 2000). Moreover, progress toward those goals may be both the best and most economical way to measure reform progress, particularly at the local level. As noted, agency heads welcomed citizen feedback and judgments on those issues, and support from the new Karnataka executive played a major role in the success of the project. These latter two sources of strength, reflections of India's surprisingly durable democracy, may not be available in all cases, but even where they are not, citizen input and agency responsiveness regarding technical, "non-political" issues can be a place to start.

BATF's growth is also built upon a diverse repertoire of incentives. The purposive incentives are clear, and in this instance the links between civil society and governmental leaders provide clear political incentives too. But it is also worth noting that BATF's broad base of support, and perceived effectiveness, help create solidary appeals: business, and leaders in both government and civil society, who support the coalition are affiliating themselves with a popular, prestigious body, and are in a position not only to back, but also to take partial credit for, anti-corruption successes and improvements in local services. Solidary incentives extend to ordinary citizens as well: taking part in 
community meetings, and the possible feeling that one is doing something about local problems, can be a source of gratification and enjoyment - as can the sense that someone in local government cares enough to listen. Recognition from BATF for successful initiatives at both the governmental and community level is also valuable in itself.

It is not clear at this point whether BATF has begun to develop material incentives to any significant degree (though improvements in governance and services, and reductions in the massive corruption levels alluded to above, certainly promise material gains in the long run). Unlike Ghana, where GACC's links to government leaders are in a sense both too extensive and too weak, it may be that BATF is too dependent upon committed and enlightened officials; if the day comes when it no longer enjoys support within state and city government, or its criticisms of corruption and poor services begin to arouse official antagonism, significant problems may result. These are additional reasons to augment the purposive and solidary appeals of the coalition with at least some limited material incentives - indeed, incentives for which BATF can take clear credit. Still, Bangalore offers us an example of a coalition-building effort that has achieved visible success, enjoys broad-based support, and is able to link anti-corruption activities effectively with a drive for improved government more generally. In that sense it is well into the Expansion phase of our developmental schema, at the very least, and has likely embarked upon Transformation.

\section{PART III: WHERE TO GO FROM HERE?}

\section{Implications and Opportunities}

Our cases do not come close to exhausting the full range of coalition-building possibilities and challenges. But several key points from our discussion in Part I stand out as common elements. There are contrasts as well from that discussion; some of these point to questions for further analysis, and others to problems coalition partners must address.

Clearly the notion of working in a cooperative relationship with government enjoys wide acceptance. Not only have our coalitions (so far) avoided confrontations; in each case extensive coordination and information-sharing efforts are apparent. Sooner or later, however, all coalitions will have to address the question of detailed working relationships between the public and private sector. To what extent does official participation in anti-corruption activities create conflicts of interest, or threaten the necessary autonomy of both the officials and their agencies on the one hand, and of the coalition on the other? Does such participation create incentives and opportunities that serve neither officials nor the coalition well? For example, an official might use extensive coalition activity to distract attention from corrupt processes continuing within his or her agency, or might feel coalition activities threaten the confidentiality of proprietary data. Or - and perhaps more likely, based on the cases we have considered - official participation and government support of the coalition may well be pro forma only. The reluctance of the Ghanaian government to designate coalition participants on its side of 
the table, as contrasted with the active support of important officials and agencies in Bangalore, is just one example. What will happen when difficult situations arise, be they in the form of public scandals that must be addressed, or of the appearance of greater corruption that may well accompany the early stages of serious reforms? Extensive cooperation will be essential, but will there be people, structures, and incentives sufficient to sustain it?

More variation is apparent in the patterns of leadership, agenda-setting and implementation. In Ghana, initiative has come from above (a factor that doubtless has reinforced the strategy of collective ownership of the corruption issues, but is also raising problems of cooperation among elites); in Bangalore, it began with information-gathering at the grassroots. In Ghana the emphasis has been on collective ownership and action; Bangalore's case attests to what can be accomplished when citizen initiative is joined with, and shaped by, commitment leadership from above. Very likely this is a goal in both cases, but will have to be approached from quite different starting points.

Another common problem is the heavy reliance upon purposive incentives. Given the nature of reform, and in light of the need to raise the corruption issue both on the elite agenda and in the popular consciousness, this is hardly a surprising pattern. What is also apparent, however, is that relatively few other incentives are on offer. There are good reasons for this, particularly in the early stages: to the extent that material resources are scarce - and they are likely to be so in most high-corruption societies - early reliance upon purposive incentives (if only by default) is understandable. Collective and specific solidary incentives, by definition, require a working organization before they can be made available. But other kinds of incentives must be created and deployed as soon as possible, for several reasons. Purposive appeals are fragile - vulnerable not only to "free rider" problems, but also to changes in political and economic circumstances, public opinion, and policy agendas, and not by themselves a promising way to sustain a group. Specific solidary and exclusive material incentives are an important hedge against these kinds of risks. Relatively few of either have been deployed as yet, although the Governance Partnership, a recent coalition-building project in Indonesia, has been able to offer funding to local projects (an exclusive material incentive), as has Bulgaria's Coalition 2000. Obtaining such resources can be difficult, and doing so may compromise the coalition's integrity and independence; but any exclusive material incentives, even in very small amounts, would be of immense value both for building support and demonstrating credibility.

In the long run, a truly independent coalition will need its own paid staff. Volunteers are unlikely to provide sustained effort and continuity; this is why George Washington Plunkitt, a colorful figure in Tammany Hall's very dirty New York City machine, likened reformers to "mornin' glories" that make a bright appearance but do not linger, and correctly observed that those whose livelihoods depend upon politics are the most reliable source of work and support (Riordon, 1963 ed.: 17-20). Reliance upon seconded government staff undermines autonomy and credibility, and may well leave the coalition dependent upon such information as officials choose to give them. Funding for staff may be obtainable from international partners for a time, but cannot and should not 
become a permanent source. Businesses, large individual donors (a source that may pose its own risks), and to a much lesser extent, civil society groups are the likely targets for fundraising; and there, a variety of exclusive material and specific solidary incentives are likely to be required. The former need not be immensely expensive, but may still take considerable time and effort to assemble: "corruption insurance" schemes, data- and information banks, or similar arrangements for providing legal and technical advice can be of real value to business and NGO members but require staff, time, and expertise. Fortunately, specific solidary incentives are easier to obtain: various citations, awards and other kinds of recognition need cost little or nothing. They are a potentially effective way to build sustaining support, gather critical resources in the credibility and expansion phases, and publicize the coalition, its activities, and its benefactors. Such recognition can of course diminish in value if carried to excess, or if the coalition itself does not earn its own prestige and effectiveness. But particularly during the credibility and expansion phases, such incentives will be essential.

If civil society is to become a full partner-always a long-term project, but essential to the transformation phase-purposive incentives will again be insufficient by themselves. Some exclusive material incentives may be available: ordinary citizens may value advice on how to avoid corruption, how to obtain various licenses and permits, or whom to approach with reports of abuses; but restricting most such benefits to members only will be self-defeating. Such restrictions will quickly create image problems, and while support at the grassroots level is critical actual membership is not likely to be common. Collective solidary appeals, however, can fill the gap. We have already mentioned sociability and fellowship: simply offering people (particularly the young) the opportunity to gather, have fun, and raise morale - always under the well-publicized aegis of the coalition, as Hong Kong's ICAC showed - can win favorable visibility in the eyes of citizens, the press, and elites. Bangalore used other collective solidary incentives: community meetings to discuss common problems, the opportunity to take part in "report card" projects, and the sense that the coalition is reaching out for one's opinions and personal knowledge (and takes them seriously) can be very valuable. Clearly these incentives are closely related to the purposive agenda; indeed, the more they overlap, the better in terms of the utility of purposive appeals. But particularly in the expansion and transformation phases, the rewards flowing from participation in coalition activities can cost very little, and yet link the coalition's purposive agenda to the day-to-day needs of citizens.

A similar synergy between the purposive and the collective solidary-one that may be of particular value in the credibility phase — can be achieved through anticorruption pacts of many sorts. These could be among bidders on contracts large or small, or on privatizations. Or, small business owners and stallholders at local markets could agree that they will not make shakedown payments to police and inspectors, but will instead report all such demands to the coalition and to authorities. The coalition, for its part, can back up these pacts with offers of legal services and access to journalistsagain, clear evidence of credibility. In the long run, the ability to pay victims of such harassment even a small amount of compensation (or to obtain it from official sources) would give many people strong reasons to join and support the anti-corruption 
movement. No doubt, such pacts can entail risk: the police may threaten violence, and inspectors can be counted on to issue numerous citations for violations that would otherwise escape the naked eye. But the strength that lies in numbers is both an asset in the pact-making process and a long-term goal in itself. Making anti-corruption pacts public from the start, under the auspices of a credible and prestigious public-private coalition, increases the likelihood that government officials and third parties will take them seriously, and may help rein in the harassment of pact makers. Ministers and mayors whose subordinates are seen abusing the parties to a well-publicized noncorruption pact can be subjected to many kinds of pressure.

The prestige and credibility of the coalition itself are important parts of the incentive system. Rewards and commendations will be worth even more, pacts will be taken more seriously, and opportunities for mass participation will be all the more attractive if the coalition is seen as honest, prestigious, and broad-based. For this reason the early agenda is critical. Hong Kong's repatriation and conviction of the corrupt police official provides a classic example; the "quick wins" attained by BATF in Bangalorewinning the clear attention of agency heads, reforming the property-tax assessment process - are others. As noted above, early targets should not necessarily be the most serious corruption problems or the biggest fish. Early victories should be seen as ways of building credibility and prestige that can be parlayed into solidary incentives.

Many of the observations offered here are familiar ones; what we offer is the notion of sustaining the activities of an anti-corruption coalition through a comprehensive and diverse repertoire of incentives, and of understanding its development not just in terms of adding size but rather as an evolutionary process involving qualitative change. Understanding the challenges this way not only can help reform leaders assess their progress in organization-building, and find ways to make the critical transition from launching a movement with a noble purpose to fielding a sustainable organization capable of effective action. It can also identify relatively easy-to-create rewards and appeals useful in winning over key constituencies, and suggest ways in which activities that might seem peripheral to the core mission may actually be important ways to sustain it. At the same time, a significant danger, particularly in the expansion phase, is "goal displacement" - that is, confusing means with ends. Many an organization loses its way as fundraising in particular, as well as other maintenance activities, come to dominate the agenda and drive broader goals off it. By emphasizing the different structures, challenges, and activities that mark the later stages of development, we hope we have identified ways of avoiding this problem. Fundamentally, however, it will always be important to retain the focus on the coalition as part of a broader push toward better governance, social and economic development, and reduced corruption.

\section{Conclusion}

Coalition building to fight corruption is more of a metaphor than a blueprint: effective social action coalitions will differ considerably in organization, tactics, and agendas from one society to the next. The key to the strategy is a mix of continuity and adaptation. The former depends upon a solid internal economy of incentives, while the latter requires 
leadership aware of the broader need for political will and a strong civil society, of the role a social action coalition can play in linking and supporting them, and of the transitions and changes that will affect the movement in the course of its long-term development. International partners can contribute in many ways: continuity can be enhanced, without excessive outside interference or an overly close public linkage between the coalition and "outsiders", by sharing expertise and information, particularly with similar anti-corruption movements in other societies. Training is also an important form of aid; over the medium to long term, however, international backers will need to shift the emphasis from training by outsiders to helping various anti-corruption coalitions train each other. Judicious application of funding - not only for permanent staff in the early phases, but also for publicity, and for small grants that can be converted into exclusive material incentives at the discretion of local coalition leadership - can pay long-term dividends far exceeding the sums contributed.

A less cheerful role for international partners-but one that will undoubtedly arise - is as a "guarantor" in case of disaster. A transition from a friendly to a hostile regime, a rise of repression, or significant social dislocations may compel a coalition to suspend or sharply curtail its activities for a time. At such points it is important that knowledge, records, and "institutional memory" not be lost, and that the anti-corruption story and the coalition's image not be forfeited to hostile interests or to fate. International partners can help maintain external sets of archives and an independent communications network - via websites, email and fax networks, by keeping archives (and people?) in a safe place - making it much easier for activities to resume once a crisis has passed.

Even with all of those factors in place, success is far from a certainty, and there will be many setbacks along the way. Still, we have tried to show that even where corruption is entrenched and reformers lack critical resources it is possible to build a base for effective action. Perhaps the most important thing to remember is that coalitions are merely means toward broader ends. They are not, in themselves, the solution to the problem, but rather a framework encouraging leaders and citizens to oppose corruption because it is in their best interests to do so. They also lay the groundwork for better governance, and a stronger civil society - in effect, diffusing political will throughout society rather than depending upon individual political leaders only. To the extent that they succeed at this, they will be following the path taken by other societies that have, through contention and over time, brought corruption under control—because it has been worthwhile for people to do so. 


\section{REFERENCES AND BIBLIOGRAPHY}

Alam, M. S. 1995. "A Theory of Limits on Corruption and Some Applications." Kyklos 48(3): 419-35.

Bratton, Michael. 1989. "The Politics of Government-NGO Relations in Africa." World Development 17(4): 569-87.

Bratton, Michael. 1994. "Civil Society and Political Transitions in Africa." In J. W. Harbeson, D. Rothchild, and N. Chazan (eds.), Civil Society and the State in Africa. Boulder, CO: Lynne Rienner Publishers.

Burgess, Philip M., and James A. Robinson. 1969. "Alliances and the Theory of Collective Action: A Simulation of Coalition Processes." Midwest Journal of Political Science XIII (May), pp. 194-218.

Clay, Karen. 1997. "Trade Without Law: Private-Order Institutions in Mexican California", Journal of Law, Economics, and Organization 13, pp. 202-231.

Cooter, Robert D. 1997. "The Rule of State Law Versus the Rule-of-Law State:

Economic Analysis of the Legal Foundations of Development." In Proceedings of the Annual World Bank Conference on Development Economics 1996. Washington, D.C.: The World Bank.

De Janvry, Alain, and Elizabeth Sadoulet. 1989. "A Study in Resistance to Institutional Change: The Lost Game of Latin American Land Reform". World Development 17: 1397-1407.

Gamson, William A. 1964. "Experimental Studies of Coalition Formation." In L. Berkowitz (ed.), Advances in Experimental Social Psychology. New York: Academic Press, Vol. I.

Geddes, Barbara. 1994. Politician's Dilemma: Building State Capacity in Latin America. Berkeley: University of California Press.

Gonzalez de Asis, Maria. 2000. "Coalition-Building to Fight Corruption." Washington, DC: World Bank Institutue. Paper prepared for the Anti-Corruption Summit; access: http:/www.worldbank.org/wbi/governance/pdf/coalition summit.pdf

Gonzalez de Asis, Maria. 2000. "Reducing Corruption: Lessons from Venezuela." Washington, DC: The World Bank, PREM note number 39.

Groennings, Sven, E. W. Kelley, and Michael Leiserson (eds.). 1970. The Study of Coalition Behavior. New York: Holt, Rinehart and Winston.

Hede, Andrew, Scott Prasser, and Mark Neylan. 1992. Keeping Them Honest: Democratic Reform in Queensland. St. Lucia, Queensland, Australia: University of Queensland Press.

Isham, Jonathan, Daniel Kaufmann, and Lant Pritchett. 1996. "Civil Liberties, Democracy, and the Performance of Government Projects." World Bank, Policy Research Department, Poverty and Human Resources Division, Washington, D.C. 
Johnston, Michael. 1993. "Political Corruption: Historical Conflict and the Rise of Standards." In Larry Diamond and Marc F. Plattner, eds. The Global Resurgence of Democracy. Baltimore:

Johns Hopkins University Press.

Johnston, Michael. 1998. "What Can Be Done About Entrenched Corruption?", pp. 149-180 in Boris Pleskovic and Joseph E. Stiglitz (eds.), Annual World Bank Conference on Development Economics 1997. Washington, DC: The World Bank.

Johnston, Michael. 1999. "Party Systems, Competition, and Political Checks against Corruption", presented at a conference on "Political Corruption and Parties", Robert Schuman Center, European University Institute, Florence, Italy; revised version appears as a Center working paper.

Johnston, Michael. 2002. "The New Corruption Rankings: Implications for Analysis and Reform", presented, International Political Science Association World Congress, Québec City, Canada; in A. J. Heidenheimer and M. Johnston (eds.), Political Corruption: Concepts and Contexts. New Brunswick, NJ: Transaction.

Klitgaard, Robert, and Heather Baser. 1997. "Working Together to Fight Corruption: State, Society, and the Private Sector in Partnership". In S. Taschereau and J. E. L. Campos, eds., Governance Innovations: Lessons from Experience, Building Government-Citizen-Business Partnerships. Washington, D.C.: Institute on Governance, pp. 59-81.

Klitgaard, Robert, Ronald Mclean-Abaroa, and H. Lindsay Parris. 2000. Corrupt Cities. Oakland, CA: Institute for Contemporary Studies Press.

Knack, Stephen, and Philip Keefer. 1995. "Institutions and Economic Performance: CrossCountry Tests Using Alternative Institutional Measures.” Economics and Politics 7(3): 207-27.

Kpundeh, Sahr, 1998 "Political Will in Fighting Corruption" in Corruption and Integrity Improvement Initiatives in Developing Countries, edited by Sahr Kpundeh and Irene Hors (UNDP/OECD).

Mahon, John F., and Barbara Bigelow. 1990. "Coalitions: The Strategic Bridge within and across Organizations". Boston University School of Management, working paper no. 90-68.

Mair, Peter (with Richard S. Katz). 1997. "Party Organization, Party Democracy, and the Emergence of the Cartel Party". Ch. 5 (pp. 93-119) in Peter Mair, Party System Change: Approaches and Interpretations. Oxford: Clarendon Press.

Mauro, Paolo. 1997. "The Effects of Corruption on Growth, Investment, and Government Expenditure: A Cross-Country Analysis." In Kimberly A. Elliott (ed.), Corruption and the Global Economy. Washington, D.C.: Institute for International Economics.

Nickson, R. Andrew. 1996. "Democratization and Institutional Corruption in Paraguay". In Walter Little and Eduardo Posada-Carbó, eds., Political Corruption in Europe and Latin America. New York: St. Martin's Press, pp. 237-266.

Olson, Mancur. 1965. The Logic of Collective Action. Cambridge, MA: Harvard University Press. 
Olson, Mancur, and Richard Zeckhauser. 1966. "An Economic Theory of Alliances." Review of Economics and Statistics XLVIII (August), pp. 266-279.

Paul, Samuel. 1995. "Evaluating Public Services: A Case Study on Bangalore, India." New Directions for Evaluation, American Evaluation Association, no. 67 (Fall).

Pharr, Susan J., Robert D. Putnam. 2000. Disaffected Democracies. Princeton, NJ: Princeton University Press.

Putnam, Robert D. 2000. Bowling Alone: The Collapse and Revival of American Community. New York: Simon and Schuster.

Riordon, William L. 1963 ed. Plunkitt of Tamanny Hall. New York: E. P. Dutton.

Roberts, Clayton. 1980 ed. The Growth of Responsible Government in Stuart England. Cambridge: Cambridge University Press.

Rose-Ackerman, Susan. 1999. Corruption and Government: Causes, Consequences, and Reform. Cambridge: Cambridge University Press. (see esp. Ch. 11).

Rounds, David. 1970. Coalitions. New York: Dutton.

Ruzindana, Augustine. 1997. "The Importance of Leadership in Fighting Corruption in Uganda." In Kimberly A. Elliott, ed., Corruption and the Global Economy. Washington, D.C.: Institute for International Economics.

Stapenhurst, Frederick, and Sahr J. Kpundeh. 1998. "Public Participation in the Fight Against Corruption." Canadian Journal of Development Studies XIX:3, pp. 491-508.

Tendler, Judith. 1979. "Rural Works Programs in Bangladesh: Community, Technology and Graft". Transportation Department, The World Bank, Washington, D.C.

Uslaner, Eric M. 2001. "Trust and Corruption." Paper presented at the Conference on Political Scandals Past and Present, University of Salford, England (June 21-23).

Wilson, James Q. 1973. Political Organizations. New York: Basic Books. 